\title{
Anti-diabetic Potency and Characteristics of Probiotic Goat-Milk Yogurt Supplemented with Roselle Extract during Cold Storage
}

\author{
R. R. S. Wihansaha, I.I. Arief ${ }^{b, *}, \&$ I. Batubara ${ }^{c, d}$ \\ aGraduate School, Study Program of Animal Production and Technology, Faculty of Animal Science, \\ Bogor Agricultural University \\ ${ }^{b}$ Department of Animal Production and Technology, Faculty of Animal Science, Bogor Agricultural University \\ Jalan Agatis, Kampus IPB Darmaga Bogor 16680, Indonesia \\ 'Department of Chemistry, Faculty of Mathematics and Natural Sciences, Bogor Agricultural University \\ Jalan Tanjung, Kampus IPB Darmaga Bogor 16680, Indonesia \\ ${ }^{d}$ Tropical Biopharmaca Research Center, Bogor Agricultural University \\ Jalan Taman Kencana No. 3, Bogor 16128, Indonesia \\ *Corresponding author: irma_isnafia@yahoo.com \\ (Received 11-04-2018; Reviewed 21-06-2018; Accepted 14-08-2018)
}

\begin{abstract}
This study aimed to evaluate the anti-diabetic potency by in vitro method and the characteristics of probiotic goat-milk yogurt supplemented with roselle extract during cold storage. The experiment used three treatments namely yogurt, probiotic yogurt, and probiotic yogurt supplemented with roselle extract. Yogurt was stored in cold storage $\left(4^{\circ} \mathrm{C}\right)$ and was evaluated for the characteristics and anti-diabetic potency on days $0,5,10$, and 15 . The anti-diabetic potency was analyzed by $\alpha$-glucosidase inhibitory activity. The results showed that goat milk in this study had a good quality including fat, SNF, protein, lactose content, density, and freezing point. Roselle extract had anti-diabetic potency with $87.72 \%$ inhibition at $25 \%$ concentration and also had $13.64 \% \mathrm{IC}_{50}$ value. The anti-diabetic potency was affected by the type of yogurt, storage duration, and their interaction $(\mathrm{P}<0.05)$. Viscosity and water activity were affected by storage duration $(\mathrm{P}<0.05)$, meanwhile titratable acidity and $\mathrm{pH}$ value were affected by the type of yogurt. Total lactic acid bacteria were affected by storage duration, and there was an interaction between the type of yogurt and storage duration. In conclusion, probiotic yogurt supplemented with roselle extract had the highest anti-diabetic potency among all treatments with $36.70 \%$ inhibition. The inhibitory activity of probiotic yogurt supplemented with roselle extract decreased during 15 days of cold storage. The inhibition was comparable with acarbose at 0.1-0.5 ppm concentration. Physical, chemical, and microbiological characteristics of yogurt in this study were good and could be consumed up to 15 days of cold storage.
\end{abstract}

Keywords: yogurt, goat milk, probiotic, roselle extract, anti-diabetic potency

\section{INTRODUCTION}

Diabetes is a chronic disease that occurs either when the pancreas does not produce enough insulin, or when the body cannot effectively use the insulin produced (WHO, 2016). This condition results in high blood glucose levels. Regulation of blood glucose levels through inhibition of glucose absorption in the intestine is one of therapeutic approach for managing type-2 diabetes including the use of a-glucosidase inhibitors. $\alpha$-Glucosidase is an enzyme located in the brush-border membrane of the intestine that catalyzes the transformation of complex carbohydrates into glucose to be absorbed by the gut (Arungarinathan et al., 2011). Inhibiting the activity of $\alpha$-glucosidase can reduce glucose absorption, thereby decreasing blood glucose levels. The mechanism of $\alpha$-glucosidase inhibitors has been used in therapeutic drugs for type-2 diabetes such as acarbose. However, the use of acarbose, a synthetic drug, has certain side effects such as abdominal pain, flatulence, and possibly diarrhea (Nakhaee \& Sanjari, 2013).

Functional foods are food that can be satisfactorily demonstrated to affect beneficially one or more target functions in the body, beyond adequate nutritional effects, in a way relevant to an improved state of health and well-being and or reduced the risk of diseases (Jitendra \& Amit, 2015). One of the most popular functional foods is yogurt. Yogurt is fermented milk using lactic acid bacteria as starter culture. Mixed culture of Streptococcus thermophilus and Lactobacillus bulgaricus are commonly used as starter culture for yogurt, but both of them cannot survive in the digestive tract. Therefore, it requires probiotics that not only capable of surviving passage through the digestive tract but also have the capability to proliferate in the gut. Lactobacillus acidophilus IIA-2B4 is one of the probiotics that can be used as a starter culture. L. acidophilus IIA-2B4 was isolated from beef obtained from Indonesian cattle, Peranakan Ongole (Arief et al., 2015). These bacteria had met the 
requirements to be classified as probiotic and also had displayed a remarkable ability to prevent EPEC-causing diarrhea (Arief et al., 2010). These bacteria had been used as a starter culture for yogurt and fermented lamb sausage (Suharto et al., 2016; Sulaiman et al., 2016). In this research, L. acidophilus IIA-2B4 was used as a probiotic. Yogurt is commonly made from cow milk, but there is the other milk that can be used such as goat milk. Although the production of goat milk is lower compared to cow milk, there are many advantages of goat over cow milk from a nutritional point of view including smaller and a greater surface area of milk fat globules and casein micelles allowing a better digestion, a higher proportion of fatty acids with health benefits, and casein composition closer to human casein composition associated with a lower allergenicity (Arora et al., 2013).

Yogurt has much functionalities, including its potency as an anti-diabetic food through the mechanism of $\alpha$-glucosidase inhibition (Apostolidis et al., 2006). Yogurt generates bioactive peptide during fermentation through proteolysis activity. Several bioactive peptides found to be able to inhibit the activity of $\alpha$-glucosidase enzyme (Lacroix \& Li-Chan, 2013). Probiotic also has been reported to have an anti-diabetic effect. Zeng et al. (2016) reported that Lactobacilli probiotic has a potency to be anti-diabetic probiotics due to its ability to act as $\alpha$-glucosidase inhibitor.

Currently, yogurt is served with the addition of a natural agent to improve the functional properties and also for food diversity. Roselle (Hibiscus sabdariffa L.) is one of natural agents that can be added to yogurt. Roselle is known as a folk medicinal plant. The plant is mostly appreciated for its anthocyanin and organic acids contents (Al-Mandawi, 2015). Recent studies have shown that plant-based food containing high phenolic compounds and flavonoids yield can be linked to intestinal $\alpha$-glucosidase inhibitory activities (Abou-arab et al., 2011). Goat milk yogurt with addition of L. acidophilus IIA-2B4 and roselle extract had been studied previously and reported to have antihypertensive, antimicrobial, and antioxidant activity (Arief et al., 2016; Hanifah et al., 2016; Suharto et al., 2016). To our knowledge, another potency of goat milk yogurt with addition of L. acidophilus IIA-2B4 and roselle extract that has not been reported is anti-diabetic potency. The anti-diabetic potency is certainly coupled with the good quality of yogurt and is expected to be durable through storage. However, the quality and functionality of food product such as yogurt may change during storage. Therefore, the objective of this study was to evaluate the anti-diabetic potency by in vitro method and the characteristics of probiotic yogurt made from goat milk supplemented with roselle extract during cold storage.

\section{MATERIALS AND METHODS}

\section{Materials}

Goat milk was obtained from Cordero Farm, Bogor, Indonesia. Yogurt cultures starter (S. thermophiles
RRAM-01, L. bulgaricus RRAM-01, and L. acidophilus IIA2B4 1:1:1) were obtained from culture collection of the Laboratory of Animal Product Technology, Faculty of Animal Science, Bogor Agricultural University. Roselle flowers were obtained from Gunung Batu traditional market, Bogor, Indonesia.

\section{Analysis of Raw Goat-Milk Quality}

The qualities of raw goat milk including fat, solid non-fat (SNF), protein, and lactose contents, density and freezing point were analyzed using Lactoscan SP60 serial number 0129.

\section{Roselle Extraction}

A 50-mesh sieve dried roselle-flowers powder was dissolved in the water $(20 \mathrm{~g}: 100 \mathrm{~mL})$ and pasteurized at $63-65{ }^{\circ} \mathrm{C}$ for $30 \mathrm{~min}$. The filtrate was evaporated and lyophilized to yield a freeze-dried roselle extract. The freeze-dried roselle extract kept in freezer $\left(20{ }^{\circ} \mathrm{C}\right)$ for subsequent use (Modification Tsai et al., 2002).

\section{Yogurt Production}

Bacteria used as starter in this research were sub-cultured by inoculating $10 \%$ of yogurt starter into sterile milk, and then incubated at $37^{\circ} \mathrm{C}$ for $18 \mathrm{~h}$ to form coagulation in order to obtain bulk culture. Goats milk was heated at $85-90{ }^{\circ} \mathrm{C}$ for $35 \mathrm{~min}$, then cooled until the temperature reached $40-45^{\circ} \mathrm{C}$. Bulk culture containing $S$. thermophillus RRAM-01 and L. bulgaricus RRAM-01 (1:1) were added to goats milk for yogurt treatment, and bulk culture containing $S$. thermophillus RRAM-01, L. bulgaricus RRAM-01, and L. acidophilus IIA-2B4 (1:1:1) were added to goats milk for probiotic yogurt and roselle probiotic yogurt treatment. Incubation was conducted at $37{ }^{\circ} \mathrm{C}$ for $16 \mathrm{~h}$ to form coagulation. Then, it was added with $1 \%$ of roselle extract for roselle probiotic yogurt treatment. All types of yogurt were stored at cold temperature $\left( \pm 4{ }^{\circ} \mathrm{C}\right.$ ) with different storage times (Donkor et al., 2006)

\section{Analysis of Yogurt Quality}

The quality of yogurt was determined for its viscosity by Rion VT-04F viscotester (Japan), water activity by Novasina $a_{w}$ meter ms1 set $a_{w}$ (Swiss), titratable acidity, $\mathrm{pH}$ by $\mathrm{pH}$ meter Schoot Instrument Lab 850 (Deutschland) (AOAC, 2005), and Total lactic acid bacteria (BAM, 2001).

\section{Yogurt Extraction (Shori \& Baba, 2014)}

The amount of $10 \mathrm{~g}$ of sample was homogenized with $2.5 \mathrm{~mL}$ of sterile distilled water, and the $\mathrm{pH}$ was adjusted to 4.0 using $1 \mathrm{M} \mathrm{HCl}$. The mixture was incubated in waterbath at $45^{\circ} \mathrm{C}$ for $10 \mathrm{~min}$, then centrifuged (10060 g, $\left.4{ }^{\circ} \mathrm{C} 10 \mathrm{~min}\right)$. The supernatant was harvested, and the $\mathrm{pH}$ was adjusted to 7.0 using $\mathrm{NaOH}(0.5 \mathrm{M})$ followed by another centrifugation $\left(10060 \mathrm{~g}, 4{ }^{\circ} \mathrm{C} 10 \mathrm{~min}\right)$. 
The supernatant was harvested and kept refrigerated until subsequent analysis.

\section{$\alpha$-Glucosidase Assay (Sancheti et al., 2009)}

A $10 \mu \mathrm{L}$ of sample (acarbose, roselle extract, yogurt extract), $50 \mu \mathrm{L}$ of $0,1 \mathrm{M}$ phosphate buffer ( $\mathrm{pH} 7), 25 \mu \mathrm{L}$ of $\alpha$-glucosidase solution $(0.04 \mathrm{U} / \mathrm{mL})$, and $25 \mu \mathrm{L}$ of P-nitrophenyl a-D-glucopyranoside $10 \mathrm{mM}$ were dissolved in $0.1 \mathrm{M}$ phosphate buffer $\mathrm{pH}$ 7.0. The mixtures were then incubated at $37{ }^{\circ} \mathrm{C}$ for $30 \mathrm{~min}$. The reaction was terminated by the addition of $100 \mu \mathrm{L}$ of $0.2 \mathrm{M}$ sodium carbonate. Absorbance was recorded at $410 \mathrm{~nm}$ using micro plate reader. All experiments were carried out in triplicates.

\section{Statistical Analysis}

The experimental design used in this study was a randomized block design with a $3 \times 4$ factorial arrangement. The first factor was the type of yogurt consisted of 3 levels i.e., yogurt, prebiotic yogurt, and prebiotic yogurt supplemented with roselle extract. The second factor was duration of storage in cold temperature consisted of 4 levels i.e., 0, 5, 10, and 15 days. An ANOVA was performed using the general linear model's procedure to determine the significant differences among the samples. Means were compared using Least square Means procedure. Three replications were used in this study. All statistical analysis were performed using SAS version 9.0 (SAS Institute Inc., Cary, NC, USA) (Steel \& Torrie, 1980).

\section{RESULTS}

\section{Quality of Raw Goat-Milk}

The quality of raw goat-milk used in this study is shown in Table 1. The data were compared to Indonesian National Standard 01-3141-2011 for raw milk and Thai Agricultural Standard 6006-2008 for raw goatmilk. Fat and protein contents in this milk had fulfilled Indonesian National Standard and Thai Agricultural Standard, solid non-fat had fulfilled Indonesian National Standard, and freezing point had fulfilled Thai Agricultural Standard. However, the density was below Indonesian National Standard and Thai Agricultural Standard. Goat milk in this study contained 3.54\% lactose.

Table 1. Quality of goat milk

\begin{tabular}{lccc}
\hline Variables & Cordero farm & SNI $^{\mathrm{a}}$ & $\mathrm{TAS}^{\mathrm{b}}$ \\
\hline Fat $(\%)$ & 8.89 & Min 3 & $>4$ \\
SNF $(\%)$ & 7.82 & Min 7.8 & $>8.25$ \\
Density $(\mathrm{g} / \mathrm{mL})$ & 1.024 & Min 1.027 & 1.028 \\
Lactose $(\%)$ & 3.54 & - & - \\
Protein $(\%)$ & 3.7 & Min 2.8 & $>3.4$ to 3.7 \\
Freeze point $\left({ }^{\circ} \mathrm{C}\right)$ & -0.462 & -0.520 to -0.560 & $<-0.530$ \\
\hline
\end{tabular}

Note: SNI= Indonesian National Standard No 01-3141-2011 year 2011; TAS= Thai Agricultural Standard No 6006-2008 year 2008.

\section{$\alpha$-Glucosidase Inhibitory Activity of Acarbose}

Acarbose was used in this study as a positive control. Data of $\alpha$-glucosidase inhibitory activity of acarbose is shown in Table 2. The data showed that acarbose had a strong $\alpha$-glucosidase inhibitory activity. Various concentrations of acarbose were used in this study and showed inhibitions from $24.88 \%$ to $96.27 \%$ with 2.69 ppm $\mathrm{IC}_{50}$ value.

\section{Characteristics of Roselle Extract}

Roselle extract in this experiment was analyzed for its $\mathrm{pH}$, moisture content, yield, $\alpha$-glucosidase inhibitory activity, and $\mathrm{IC}_{50}$ value. The results showed that roselle extract has $2.34 \mathrm{pH}$ value, $18.76 \%$ yield, and contained $11.67 \%$ moisture content (Table 3 ). The $\alpha$-glucosidase inhibitory activity of roselle extract at the highest concentration $(25 \%)$ was $87.72 \%$ with $13.64 \% \mathrm{IC}_{50}$ value.

\section{Physical, Chemical, and Microbiological Quality of Yogurt}

The viscosity of yogurt in this experiment was significantly affected by storage duration $(\mathrm{P}<0.05)$, but it was not affected by the type of yogurt (Table 4 ). There was no interaction between the type of yogurt and storage duration. On the day- 5 of cold storage, the viscosity values significantly increased $(\mathrm{P}<0.05)$, and then stable until day-15 of cold storage. The water activity value (Table 4) was significantly affected by the storage duration $(\mathrm{P}<0.05)$, but it was not significantly affected by the type of yogurt (Table 4 ). There was no interaction between the storage duration and the type of yogurt. Water activity value obtained ranged from 0.80 to 0.83 .

Table 2. Concentration and $\alpha$-glucosidase inhibitory activity of acarbose

\begin{tabular}{cccc}
\hline Sample & $\begin{array}{c}\text { Concentration } \\
(\mathrm{ppm})\end{array}$ & $\begin{array}{c}\text { Inhibition } \\
(\%)\end{array}$ & $\begin{array}{c}\mathrm{IC}_{50} \\
(\mathrm{ppm})\end{array}$ \\
\hline Acarbose & 0.1 & $24.88 \pm 0.98$ & $2.69 \pm 0.02$ \\
& 0.5 & $33.45 \pm 0.00$ & \\
& 1 & $41.23 \pm 0.00$ & \\
& 5 & $73.59 \pm 3.75$ & \\
& 10 & $96.27 \pm 0.04$ & \\
\hline
\end{tabular}

Table 3. Characteristics of roselle extract

\begin{tabular}{lcc}
\hline Variables & \\
\hline $\mathrm{pH}$ & & $2.34 \pm 0.01$ \\
Water content $(\% \mathrm{bb})$ & & $11.67 \pm 0.39$ \\
Rendemen $(\%)$ & 18.76 \\
\hline Concentration (\%) & Inhibition of & $\mathrm{IC}_{50}(\%)$ \\
\multicolumn{1}{c}{0.1} & $\alpha$-glucosidase $(\%)$ & \\
0.5 & $1.52 \pm 0.00$ & $13.64 \pm 0.13$ \\
5 & $10.78 \pm 0.01$ & \\
20 & $31.21 \pm 0.46$ & \\
25 & $68.26 \pm 0.00$ & \\
\hline
\end{tabular}


Table 4. Physical, chemical, and microbiological qualities of yogurt during cold storage

\begin{tabular}{|c|c|c|c|c|c|c|}
\hline \multirow{2}{*}{ Variables } & \multirow{2}{*}{$\begin{array}{l}\text { Type of } \\
\text { yogurt }\end{array}$} & \multicolumn{4}{|c|}{ Storage duration (days on-) } & \multirow{2}{*}{ Average } \\
\hline & & 0 & 5 & 10 & 15 & \\
\hline \multirow[t]{3}{*}{ Viscosity (dPa.s) } & $\mathrm{Y}$ & $3.11 \pm 0.01$ & $3.52 \pm 0.1$ & $3.59 \pm 0.07$ & $3.59 \pm 0.11$ & $3.45 \pm 0.08$ \\
\hline & PY & $3.22 \pm 0.01$ & $3.49 \pm 0.12$ & $3.50 \pm 0.05$ & $3.57 \pm 0.02$ & $3.45 \pm 0.05$ \\
\hline & PYR & $3.17 \pm 0.14$ & $3.47 \pm 0.26$ & $3.49 \pm 0.07$ & $3.47 \pm 0.06$ & $3.40 \pm 0.13$ \\
\hline Average & & $3.17 \pm 0.05^{\mathrm{b}}$ & $3.49 \pm 0.17^{a}$ & $3.53 \pm 0.06^{\mathrm{a}}$ & $3.54 \pm 0.06^{\mathrm{a}}$ & \\
\hline \multirow[t]{3}{*}{ Water activity } & $\mathrm{Y}$ & $0.82 \pm 0.01$ & $0.83 \pm 0.01$ & $0.83 \pm 0.01$ & $0.82 \pm 0.01$ & $0.83 \pm 0.01$ \\
\hline & PY & $0.82 \pm 0.01$ & $0.81 \pm 0.01$ & $0.82 \pm 0.01$ & $0.83 \pm 0.01$ & $0.82 \pm 0.01$ \\
\hline & PYR & $0.80 \pm 0.00$ & $0.81 \pm 0.03$ & $0.82 \pm 0.01$ & $0.83 \pm 0.01$ & $0.82 \pm 0.01$ \\
\hline Average & & $0.81 \pm 0.01^{\mathrm{b}}$ & $0.82 \pm 0.02^{\mathrm{ab}}$ & $0.83 \pm 0.01^{\mathrm{a}}$ & $0.83 \pm 0.01^{\mathrm{a}}$ & \\
\hline \multirow[t]{3}{*}{$\mathrm{pH}$} & $\mathrm{Y}$ & $4.37 \pm 0.04$ & $4.36 \pm 0.05$ & $4.38 \pm 0.07$ & $4.34 \pm 0.02$ & $4.36 \pm 0.04^{\mathrm{a}}$ \\
\hline & PY & $3.80 \pm 0.01$ & $3.85 \pm 0.06$ & $3.86 \pm 0.02$ & $3.87 \pm 0.04$ & $3.85 \pm 0.03^{b}$ \\
\hline & PYR & $3.65 \pm 0.04$ & $3.72 \pm 0.04$ & $3.73 \pm 0.01$ & $3.74 \pm 0.04$ & $3.71 \pm 0.03^{c}$ \\
\hline Average & & $3.94 \pm 0.03$ & $3.98 \pm 0.05$ & $3.99 \pm 0.03$ & $3.98 \pm 0.04$ & \\
\hline \multirow{3}{*}{$\begin{array}{l}\text { Titratable acidity } \\
(\%)\end{array}$} & $\mathrm{Y}$ & $1.06 \pm 0.05$ & $1.33 \pm 0.09$ & $1.31 \pm 0.19$ & $1.20 \pm 0.16$ & $1.23 \pm 0.12^{\mathrm{a}}$ \\
\hline & PY & $1.45 \pm 0.06$ & $1.49 \pm 0.31$ & $1.50 \pm 0.15$ & $1.44 \pm 0.28$ & $1.47 \pm 0.20^{\mathrm{b}}$ \\
\hline & PYR & $1.89 \pm 0.14$ & $1.88 \pm 0.27$ & $1.80 \pm 0.31$ & $1.80 \pm 0.09$ & $1.84 \pm 0.21^{c}$ \\
\hline Average & & $1.47 \pm 0.08$ & $1.57 \pm 0.23$ & $1.54 \pm 0.22$ & $1.48 \pm 0.18$ & \\
\hline \multirow{3}{*}{$\begin{array}{l}\text { Total LAB (Log } \\
\mathrm{cfu} / \mathrm{mL})\end{array}$} & $\mathrm{Y}$ & $9.23 \pm 0.20^{\mathrm{b}}$ & $9.18 \pm 0.29 b$ & $9.17 \pm 0.28^{\mathrm{b}}$ & $9.13 \pm 0.25^{b}$ & $9.18 \pm 0.25$ \\
\hline & PY & $9.48 \pm 0.09^{a}$ & $9.01 \pm 0.19^{b c}$ & $9.01 \pm 0.16^{\mathrm{bc}}$ & $9.00 \pm 0.04^{\mathrm{bc}}$ & $9.13 \pm 0.12$ \\
\hline & PYR & $9.47 \pm 0.10^{\mathrm{a}}$ & $9.03 \pm 0.17^{\mathrm{bc}}$ & $8.87 \pm 0.07 c$ & $8.85 \pm 0.12^{c}$ & $9.05 \pm 0.12$ \\
\hline Average & & $9.39 \pm 0.13$ & $9.07 \pm 0.22$ & $9.02 \pm 0.17$ & $8.99 \pm 0.14$ & \\
\hline
\end{tabular}

Note: Mean in the same row or column with different superscripts differ significantly $(\mathrm{P}<0.05)$; $\mathrm{Y}=$ yogurt; $\mathrm{PY}=$ Probiotic yogurt; PYR= Probiotic yogurt yoselle.

The value of water activity increased during 15 days of cold storage.

The $\mathrm{pH}$ value of yogurt in this experiment was significantly $(\mathrm{P}<0.05)$ affected by the type of yogurt, but it was not affected by the storage duration (Table 4). There was no interaction between the storage duration and the type of yogurt. The averages of $\mathrm{pH}$ values from the highest to the lowest were 4.36, 3.85, and 3.71 for yogurt, probiotic yogurt, and probiotic yogurt supplemented with roselle extract, respectively. The type of yogurt had shown to significantly affect titratable acidity $(\mathrm{P}<0.05)$, meanwhile the storage duration did not significantly affect titratable acidity of yogurt. There was no interaction between the type of yogurt and the storage duration. The averages of titratable acidity from the lowest to the highest for yogurt, probiotic yogurt, and probiotic yogurt supplemented with roselle extract were $1.23 \%$, $1.47 \%$, and $1.84 \%$, respectively (Table 4 ). Titratable acidity of all types of yogurt were stable during 15 days of cold storage. The population of lactic acid bacteria was significantly affected $(\mathrm{P}<0.05)$ by the storage duration (Table 4). Total lactic acid bacteria of yogurt was stable during 15 days of cold storage, meanwhile the population of lactic acid bacteria on probiotic yogurt and probiotic yogurt supplemented with roselle decreased on day-5, then stable until day-15. There was an interaction between the type of yogurt and the storage duration $(\mathrm{P}<0.05)$.

\section{$\alpha$-Glucosidase Inhibitory Activity of Yogurt}

The $\alpha$-glucosidase inhibitory activity was significantly affected $(\mathrm{P}<0.05)$ by both types of yogurt and storage duration as was shown in Figure 1. There was also an interaction between the type of yogurt and the storage duration $(\mathrm{P}<0.05)$. Probiotic yogurt supplemented with roselle extract had the highest activity with $36.70 \%$ inhibition. The activity of probiotic yogurt supplemented with roselle extract was able to compare with acarbose at 0.1-0.5 ppm concentration (Table 2). The inhibitory activity of probiotic yogurt supplemented with roselle extract was significantly higher than those of yogurt and probiotic yogurt, but there was no significant difference between yogurt and probiotic yogurt. $\alpha$-Glucosidase inhibitory activity of yogurt and probiotic yogurt were found to be consistent during 15 days of cold storage, meanwhile, the inhibition activity

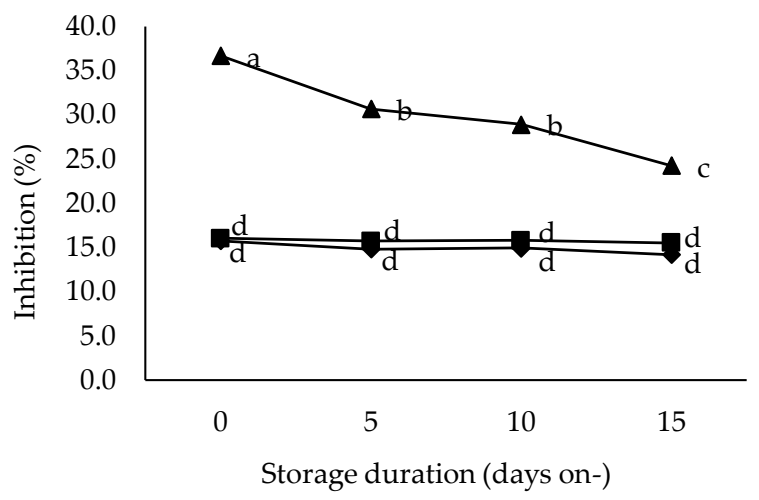

Figure 1. $\alpha$-Glucosidase inhibitory activity of yogurt $(-\bullet-)$, probiotic yogurt (-m-) and probiotic yogurt supplemented with extract Roselle (- $\boldsymbol{\Delta}-$ ) during 15 days of cold storage 
of probiotic yogurt supplemented with roselle extract decreased on day-5 and day-15 of cold storage.

\section{DISCUSSION}

\section{The Quality of Raw Goat Milk}

Fat content of goat milk in this study was classified into premium grade which had above $4 \%$ fat content according to Thai Agricultural Standard. Fat content is influenced by the quality and quantity of feeds, genetics, and the stage of lactation (Getaneh et al., 2016). Digestible fibre contained in the feeds increases the acetic acid availability for milk fat synthesis and stimulates energy partitioning towards milk synthesis instead of body fat reserve deposition (Jaafar et al., 2018). Protein content was classified into a good grade according to Thai Agricultural Standard. Goat milk in this study had the same protein content with goat milk in the study conducted by Cyrilla et al. (2015) that is 3.70\%. Protein content in goat milk is affected by protein content in the feeds. Feed with high protein content contributes to the increasing of milk protein content (Jaafar et al., 2018). Usually, concentrate becomes the source of protein for goat. The protein content is an important feature of the milk that determines the market value of the milk (Guetouache et al., 2014).

Freezing point of milk in this study had fulfilled Thai Agricultural Standard. The freezing point of milk depends upon the concentration of water-soluble components. As milk is more diluted, the freezing point will raise closer to zero (Zagorska \& Ciprovica, 2013). The percentage of solid non-fat had fulfilled Indonesian National Standard. Solid non-fat content is affected by protein and lactose content. The higher protein and lactose contents in milk contribute to the higher solid nonfat content. Lactose is a main carbohydrate contained in milk. Lactose in this milk is also a main source of energy for the growth of lactic acid bacteria in fermented milk. Milk density was below standard. It might be due to the high content of fat on milk. The density of milk depends on fat and solid contents because fat have lower density than water.

\section{$\alpha$-Glucosidase Inhibitory Activity of Acarbose}

Acarbose is a commercial drug for diabetes management with the mechanism of $\alpha$-glucosidase inhibition (Arungarinathan et al., 2011). The data in Table 2 show that acarbose had a strong $\alpha$-glucosidase inhibitory activity with 2.69 ppm $\mathrm{IC}_{50}$ value. This result is consistent with the result reported by Sulistyani et al. (2011) that acarbose had lower $\mathrm{IC}_{50}$ value i.e., $2.154 \mathrm{ppm}$. Acarbose belongs to the group of noninsulinotropic oral anti-diabetic agents through inhibition of $\alpha$-glucosidase activity. To enable glucose uptake and absorption by the body and its availability as an energy source, intestinal cleavage of starch and oligosaccharides is necessary, because only monosaccharide that can be taken up into the blood. Oligosaccharides are cleaved into monosaccharide by enzyme complexes called $\alpha$-glucosidase, which are present in the brush border membrane of the small intestine. Acarbose is structurally similar to natural oligosaccharides, but has a $10^{4}$ to $10^{5}$ time higher affinity for $\alpha$-glucosidase which means these enzymes are completely inhibited. Thus, monosaccharide formation decreases and less insulin is required for further metabolism, leading to a reduction of food-induced postprandial increases in blood glucose and insulin (Rosak \& Mertes, 2012).

\section{Characteristics of Roselle Extract}

The $\mathrm{pH}$ value of roselle extract in this experiment was higher than that in the research of Kilima et al. (2014) who obtained 2.26, but similar to Chumsri et al. (2008) who obtained 2.30-2.38. The $\mathrm{pH}$ value of roselle extract was low and acid. The acidity in roselle extract is contributed by organic acids such as citric, malic, tartaric, hibiscus, succinic, oxalic, and ascorbic acids (Cid-Ortega \& Guerrero-Beltran, 2014). Roselle extract in this experiment had low moisture content because there was a freeze-drying process. Freeze-drying technology is currently used in food industry to produce better quality and flavour of dried food products. The advantages of freeze-dried product was minimal shrinkage or structural change, minimal change in odor, flavour and color, and the prevention of bacterial spoilage because freeze-drying process could remove water content and decreased water activity (Hariyadi, 2013).

Roselle extract in this experiment proved to have $\alpha$-glucosidase inhibitory activity. That inhibitory activity might be due to the presence of dietary phytochemicals in roselle extracts such as anthocyanin, flavonoids, and phenolic compounds. Previous study by Hanifah et al. (2016) who used the same method of extraction and solvent with this study showed that aqueous extracts of roselle positively contained phenol hydroquinone, flavonoid, triterpenoid, steroid, and tannin. The presence of phenolic compound and flavonoid promotes roselle extract to exhibit anti-diabetic activity. Phenolic compound and flavonoid contained in roselle extract act as inhibitors of $\alpha$-glucosidase enzyme. It was found that non-covalent interactions occur between polyphenols and enzymes (proteins). The phenolic groups can form hydrogen bonds with the polar groups of enzyme. In contrast, there are many hydrophobic amino acids found in enzymes (protein). Therefore, polyphenols can bind enzymes through hydrophobic association (Asgar, 2013). Roselle extract affected the $\alpha$-glucosidase inhibitory activity. Roselle extract with high content of anthocyanins and phenolic compounds could possibly increase $\alpha$-glucosidase inhibitory activity. $\alpha$-Glucosidase inhibitory activity of roselle extract obtained in this study was lower than that of Roselle extract and ethanol extract of roselle in the study of Ademiluyi \& Oboh (2013) and Gondokesumo et al. (2017) who obtained IC I0 $_{50}$ values of $25.2 \mu \mathrm{g} / \mathrm{mL}$ and $15.81 \mu \mathrm{g} / \mathrm{mL}$, respectively. This lower activity might be due to the difference of extraction method, type of solvent, and the ratio of roselle and solvent used. Nevertheless, $\mathrm{IC}_{50}$ value of roselle extract was higher than acarbose (Table 2), indicating that acarbose had a stronger inhibition activity. 


\section{Physical, Chemical, and Microbiological Quality of Yogurt}

Storage duration of yogurt in cold temperature $\left( \pm 4^{\circ} \mathrm{C}\right)$ increased the viscosity of yogurt on day 5 . The increase in viscosity could be due to the existence of exopolysaccharide. Exopolysaccharide produced by lactic acid bacteria acts as a protection from extreme environmental conditions. These exopolysaccharides are produced at the stationary phase of bacteria. Exopolysaccharide can act as a stabilizer, emulsifier, thicker, and has a good water-binding ability (Nudyanto \& Zubaidah, 2014). Astawan et al. (2012) stated that cooling and storage process after fermentation increased viscosity caused by protein hydration and compaction of yogurt gel structure. The viscosities on day 5 until day 15 of cold storage were almost similar because the temperature remain stable at $\pm 4{ }^{\circ} \mathrm{C}$ and the production of exopolysaccharide by lactic acid bacteria was not as much as from day 0 until day 5. Meanwhile, on the day 0 , the yogurt was assessed for its viscosity right after incubation process at $37^{\circ} \mathrm{C}$ temperature and then placed in cold temperature $\left( \pm 4^{\circ} \mathrm{C}\right)$; it was a shocking temperature changes for bacteria.

Microorganisms have different minimum levels of water activity for growth. Higher $a_{w}$ substances tend to support more microorganisms. On the range of water activity value obtained in this experiment, bacteria possibly did not grow because according to Abbas et al. (2009), most of bacteria could not grow at water activity below 0.90 , meanwhile most of molds that had a typical growth limits of water activity at $0.70-0.80$ was possible to grow. The water activity value increased during 15 days of cold storage. This increase in water activity might be due to the molecular degradation by microorganism on yogurt resulting in the release of bound water.

As expected, yogurt treatment in this experiment had the highest $\mathrm{pH}$ due to the strains used in this treatment only S. thermophillus and L. bulgaricus. Meanwhile, probiotic yogurt which contained L. acidophilus IIA-2B4 as addition had lower $\mathrm{pH}$. This decrease in $\mathrm{pH}$ is possible since the higher lactic acid bacteria present in the yogurt, the higher acid compounds are produced. Probiotic yogurt supplemented with roselle extract in this experiment had the lowest $\mathrm{pH}$ value due to the presence of roselle extract. Roselle extract in this experiment had $\mathrm{pH}$ 2.34. The organic acids, oxalic, tartaric, ascorbic, citric, and malic were found to exist in roselle (Al-Mandawi, 2015). Organic acid contained in roselle extract contributed to the increase of total acid and the decrease of $\mathrm{pH}$. During 15 days of cold storage, $\mathrm{pH}$ values of yogurt in this experiment were stable. The stability of $\mathrm{pH}$ value was caused by the low temperature at cold storage $\left( \pm 4{ }^{\circ} \mathrm{C}\right)$. In addition, the lactic acid bacteria used in this experiment might have passed logarithmic phase when fermentation process was completed, so the decrease of $\mathrm{pH}$ was not occured during the storage.

Titratable acidity obtained in this experiment ranged from $1.06 \%$ to $1.89 \%$. These percentages meet the requirement of SNI for titratable acidity of yogurt which is ranged from $0.5 \%$ to $2.0 \%$ (BSNI, 2009). The titratable acidity in yogurt was inversely proportional to the $\mathrm{pH}$ value in Table 3 . These results were in line with Tomovska et al. (2016) who reported the decrease in $\mathrm{pH}$ value and an increase in titratable acidity in fermented milk. The content of titratable acidity of probiotic yogurt was shown to be higher than yogurt due to the presence of L. acidophilus IIA-2B4 as a probiotic. The addition of L. acidophilus IIA-2B4 has resulted in a fast lactic acid production. Probiotic yogurt supplemented with roselle extract had the highest titratable acidity among all treatments. This high titratable acidity was due to the addition of roselle extract besides the presence of $L$. acidophilus IIA-2B4. The increase in titratable acidity due to the addition of roselle extract was possibly related to the high content of organic acid and proved to have $\mathrm{pH}$ 2.34. Abdel-Moemin (2016) reported that a high percentage of organic acids contained in roselle contributed to the titratable acidity. El-Baily (2016) also reported that total acidity was increased gradually by increasing roselle percentage. In line with $\mathrm{pH}$ value, the titratable acidity in this experiment was found to be consistence during 15 days of cold storage.

The population of LAB in probiotic yogurt and probiotic yogurt supplemented with roselle extract on day0 was not significantly different, but both had a higher population than yogurt. This difference was due to the strain used as a starter culture in yogurt only 2 strains, namely $S$. thermophillus and L. bulgaricus, meanwhile probiotic yogurt and probiotic yogurt supplemented with roselle extract used 3 strains with the addition of L. acidophilus IIA-2B4. The use of mixed strain culture resulted in a fast fermentation process.

The decrease in total LAB on day- 5 was occurred because of the lack of substrate. Substrate becomes a factor affecting microbial growth. Lactic acid bacteria in this experiment might be in a stationary phase during cold storage. In this phase, the rate of bacterial growth was equal to the rate of death, and the growth rate began to decline (Marwati et al., 2018). Papadimitriou et al. (2016) stated that the LAB enters stationary phase due to the exhaustion of nutrients and/or the accumulation of toxic metabolic product in their environment during growth. Sulistijowati (2012) also stated that during stationary phase, lactic acid bacteria competed to get nutrient. Therefore, on probiotic yogurt and probiotic yogurt supplemented with roselle which used 3 strains of bacteria, the competition became stricter. Population of lactic acid bacteria in probiotic yogurt supplemented with roselle extract decreased more quickly. This higher decrease in the population of lactic acid bacteria was due to the addition of roselle extract that had antimicrobial activity. Research conducted by Malelak et al. (2017) showed that the addition of $2 \%$ and 3\% of Roselle extract on se'i decreased total plate count number due to the antimicrobial content in the roselle. The antimicrobial activity is contributed by its phytochemical constituents such as flavonoids, tannins, and saponins (Al-Mamun et al., 2011). These compounds have the ability to form combined complex with bacterial walls (Purbowati et al., 2015). Nevertheless, total LAB in this experiment during 15 days of cold storage still fulfill the standard for the presence of viable bacteria in yogurt. 
National Standardization Agency of Indonesia has established a standard that requires the presence of $\geq 10^{7}$ colony/g in yogurt (BSNI, 2009), meanwhile CODEX (2003) requires $10^{6} \mathrm{cfu} / \mathrm{mL}$ for minimum viable bacteria in yogurt.

\section{$\alpha$-Glucosidase Inhibitory Activity of Yogurt}

Yogurts in this experiment were found to have $\alpha$-glucosidase inhibitory activity. The ability of yogurt to inhibit $\alpha$-glucosidase activity due to the presence of bioactive peptides produced through proteolysis by LAB. During fermentation, protein contained in the goat milk was degraded by LAB into peptides. In these processes, varieties of peptides were formed. Once liberated and absorbed, these bioactive peptides may exert a physiological effect on the body. The activity of these peptides was based on their inherent amino acid compositions and the sequences. Many milk-derived peptides reveal multifunctional properties because specific peptide sequences might exert two or more different biological activities (Tidona et al., 2009). In the previous study conducted by Arief et al. (2016), goat milk yogurt using L. acidophilus IIA-2B4 proved to have 11.41-12.80 $\mu \mathrm{g} / \mathrm{mL}$ peptide content with $<10 \mathrm{kDa}$ fragments. Those bioactive peptides proved to have antihypertensive potency through inhibition of angiotensin converting enzyme. Patil et al. (2015) stated that milkderived peptides were capable of inhibiting the activity of $\alpha$-glucosidase so that could be used as ingredients for functional food for the management of diabetes. Lacroix \& Li-Chan (2013) found that whey protein hydrolysates obtained from dairy protein displayed $\alpha$-glucosidase inhibitory activity. It had been suggested that the binding ability of bioactive peptide to the active site or another side of enzyme resulting in a decrease in enzyme activities. Through inhibition of $\alpha$-glucosidase enzyme, the absorption of glucose could be retarded; as a result, less glucose was absorbed because the carbohydrates were not rapidly hydrolyzed down into glucose molecules. The effect of these inhibitors was to decrease the current blood glucose level or act as anti-diabetes. Even Yu et al. (2011) found the sequence of bioactive peptides derived from egg white protein that could inhibit $\alpha$-glucosidase activity. $\alpha$-Glucosidase inhibitory activities of yogurt and probiotic yogurt in this experiment were found to be higher than that of cow milk yogurt in the research of Shori \& Baba (2014) which obtained 11.3\% inhibition. The differences can be attributed to the type of strains and milk used.

The highest $\alpha$-glucosidase inhibitory activity of probiotic yogurt supplemented with roselle extract indicated that the addition of roselle extract enhanced the inhibitory activity. Roselle extract in this experiment had $\alpha$-glucosidase inhibitory activity by $87.72 \%$ at $0.25 \%$ concentration which comparable to acarbose at $5 \mathrm{ppm}$ concentration (Table 3). That inhibitory activity occurs due to the presence of phytochemical compounds in roselle extract such as anthocyanins, flavonoids, and phenolic compounds. Anthocyanins are sub-types of organic compounds of flavonoid fam- ily and are members of a large group of compounds. It was proven by the previous study that the used of the same extraction method and solvent with this study that aqueous extracts of roselle positively contained phenol hydroquinone, flavonoid, triterpenoid, steroid, and tannin (Hanifah et al. 2016). The presence of phenolic compound and flavonoid promote roselle extract to exhibit anti-diabetic activity. Phenolic compound and flavonoid contained in the roselle extract act as inhibitors of $\alpha$-glucosidase enzyme. The interaction between chemical compound from roselle extract and $\alpha$-glucosidase enzyme caused the changes in the enzyme's molecular configuration and hydrophilic and hydrophobic properties, resulting in a decrease in enzyme activities (Adisakwatanna et al., 2012). Shori \& Baba (2014) conducted a similar research using medicinal plant as a supplementation in yogurt and obtained $15.2 \% \alpha$-glucosidase inhibitory activity from cow milk yogurt supplemented with Allium sativum extract.

Although yogurt and probiotic yogurt had less inhibition activities than probiotic yogurt supplemented with roselle extract, during 15 days of cold storage the $\alpha$-glucosidase inhibitory activity of yogurt and probiotic yogurt were stable, meanwhile the activity of probiotic yogurt supplemented with roselle extract decreased from $36.70 \%$ to $24.27 \%$. This decrease was due to the loss of anthocyanin stability in the roselle extract. Anthocyanins are highly unstable molecules in food matrix. The stability is strongly affected by $\mathrm{pH}$, solvents, temperature, anthocyanin concentration and structure, oxygen, light, enzymes, and other accompanying substances (Arueya \& Akomolafe, 2014). Lawin \& Kongbangkerd (2010) showed the decrease in antioxidant activity of yogurt supplemented with roselle syrup during 6 days of cold storage due to the loss of anthocyanins stability. This result show that even in the cold temperature, there is a possibility of anthocyanin losing its stability. The decrease in $\alpha$-glucosidase inhibitory activity of yogurt was also found in the research of Shori \& Baba (2014) from 15.2\% to $12.8 \%$ during 21 days of cold storage. Nevertheless, yogurt, probiotic yogurt, and probiotic yogurt supplemented with roselle extract still have $\alpha$-glucosidase inhibitory activity up to 15 days of cold storage.

\section{CONCLUSION}

Probiotic yogurt supplemented with roselle extract had the highest anti-diabetic potency among all treatments with $36.70 \% \alpha$-glucosidase inhibitory activity. The inhibitory activity of probiotic yogurt supplemented with roselle extract decreased during 15 days cold storage, but the inhibition was comparable with acarbose at 0.1-0.5 ppm concentration. Physical, chemical, and microbiological characteristics of yogurt in this study were good and could be consumed up to 15 days of cold storage.

\section{CONFLICT OF INTEREST}

There is no conflict of interest with any financial, personal, or other relationships with other people or 
organization related to the material discussed in the manuscript.

\section{ACKNOWLEDGEMENT}

This research was supported by the 2018 Postgraduate Grant for Community Services Number 129/SP2H/PTNBH/DRPM/2018 from Ministry of Research, Technology, and Higher Education of the Republic of Indonesia.

\section{REFERENCES}

Abbas, K.A., A.M. Saleh, A. Mohamed, \& O. Lasekan. 2009. The relationship between water activity and fish spoilage during cold storage: a review. J. Food Agric. Environm. 7:86-90.

Abdel-Moemin, A.R. 2016. Effect of roselle calyces extact on the chemical and sensory properties of functional cupcakes. Food Sci. Hum. Wellness. 5:230-237. https://doi. org/10.1016/j.fshw.2016.07.003

Abou-Arab, A.A., F.M. Abu-Salem, \& E.A. Abou-Arab. 2011. Physico-chemical properties of natural pigments (anthocyanin) extracted from Roselle calyces (Hibiscus sabdariffa). J. Am. Sci. 7:445-456

Ademiluyi, A.O. \& G. Oboh. 2013. Aqueous extracts of roselle (Hibiscus sabdariffa Linn.) varieties inhibit a-amylase and a-glucosidase activities in vitro. J. Med. Food. 16: 88-93. https://doi.org/10.1089/jmf.2012.0004

Adisakwattana, S., T. Ruengsamran, P. Kampa, \& W. Sompong. 2012. In vitro inhibitory effect of plant-based foods and their combinations on intestinal $\alpha$-glucosidase and pancreatic $\alpha$-amylase. BMC Complement. Altern. Med. 12:110-118. https://doi.org/10.1186/1472-6882-12-110

Al-mamun, M., H. Khatun, M.L. Nesa, M.R. Islam, \& M.S. Munira. 2015. In vitro evaluation of the antibacterial, cytotoxic and insecticidal acivities of Hibiscus sabdariffa fruits. LARCJI. 2:144-149.

Al-Mandawi, H. 2015. Organic acid composition of different parts of the medical plant - roselle (Hibiscus Sabdariffa). International Journal of Biological \& Pharmaceutical Research. 6: 808-813.

AOAC. 2005. Official Methods of Analysis. Association of Official Analytical Chemist. USA.

Apostolidis, E., Y. I. Kwon, \& K. Shetty. 2006. Potential of select yogurts for diabetes and hypertension management. J. Food Biochem. 30: 699-717. https://doi. org/10.1111/j.1745-4514.2006.00091.x

Arief, I.I., B.S.L. Jenie, M. Astawan, \& A.B. Witarto. 2010. The effectivities of probiotic Lactobacillus plantarum 2C12 and Lactobacillus acidophilus 2B4 as antidiarrheal on rats. Med. Pet. 33:137-143. http://dx.doi.org/10.5398/ medpet.2010.33.3.137

Arief, I.I., B.S.L Jenie, M. Astawan, K. Fujiyama, \& A.B. Witarto. 2015. Identification and probiotic characteristics of lactic acid bacteria isolated from Indonesian local beef. Asian J. Anim. Sci. 9: 25-36. https://doi.org/10.3923/ ajas.2015.25.36

Arief, I.I., C. Budiman, R. Hanifah, M.S. Soenarno. 2016. Antihypertensive potency of goat milk yoghurt supplemented by probiotic and roselle extract. Int. J. Sci.: Basic Appl. Res. 30: 207-214.

Arora, R., N. Bhojak, \& R. Joshi. 2013. Comparative aspects of goat and cow milk. Int. J. Eng. Sci. Invention Res. Dev. 2:7-10.

Arungarinathan, G., G.A. McKay, \& M. Fisher. 2011. Drugs for diabetes: part 4 acarbose. Br. J. Cardiol. 18:78-81.
Arueya, G.L., \& B.O. Akomolafe. 2014. Stability studies of microencapsulated anthocyanins of roselle (Hibiscus sabdariffa L.) in native starch and its potential application in jam production. IOSR J. Environ. Sci. Toxicol. Food Technol. 8:112-122. https://doi.org/10.9790/2402-0871112122

Asgar, M.A. 2013. Anti-Diabetic potential of phenolic compounds: a review. Int. J. Food Prop. 16:91-103. https://doi. org/10.1080/10942912.2011.595864

Astawan, M., T. Wresdiyati, Suliantari, I.I. Arief, \& R. Septiawan. 2012. Production of synbiotic yogurt-like using indigenous lactic acid bacteria as functional food. Med. Pet. 35: 9-14. https://doi.org/10.5398/medpet.2012.35.1.9

[BAM] Bacteriological Analytical Manual online. 2001. U.S. Food \& Drug Administration. Center for Food Safety \& Applied Nutrition.

[BSNI] Badan Standardisasi Nasional Indonesia. 2009. SNI. 01-2981-2009: Yogurt. Jakarta (ID). Badan Standardisasi Nasional.

[BSNI] Badan Standardisasi Nasional Indonesia. 2011. SNI. 013141-2011: Susu Segar. Jakarta (ID). Badan Standardisasi Nasional.

Chumsri, P., A. Sirichote, \& A. Itharat. 2008. Studies on the optimum conditions for the extraction and concentration of roselle (Hibiscus sabdariffa Linn.) extract. Songklanakarin J. Sci. Technol. 30:133-139.

Cid-Ortega, S. \& J.A. Guerrero-Beltran. 2014. Roselle calyces particle size effect on the physicochemical and phytochemicals characteristics. J. Food Res. 3: 83-94. https://doi. org/10.5539/jfr.v3n5p83

CODEX Alimentarius Commission. 2003. CODEX standard for fermented milks. Alimentarius Commission. No. CODEX Stan 243-2003.

Cyrilla, L., B.P. Purwanto, A. Atabany, D.A. Astuti, \& A. Sukmawati. 2015. Improving milk quality for dairy goat farm development. Med. Pet. 38:204-211. https://doi. org/10.5398/medpet.2015.38.3.204

Donkor, O.N., A. Henriksson, T. Vasiljevic, \& N.P. Shah. 2006. Effect of acidification on the activity of probiotics in yoghurt during cold storage. Int. Dairy J. 16: 1181-1189. https://doi.org/10.1016/j.idairyj.2005.10.008

El-Baily, A.R. 2016. Chemical, microbiological and sensory evaluation of probiotics beverages prepared with permeate and roselle. Int. J. Curr. Microbiol. App. Sci. 5:802-811. https://doi.org/10.20546/ijcmas.2016.501.082

Getaneh, G., A. Mebrat, A. Wubie, \& H. Kendie. 2016. Review on goat milk composition and its nutritive value. J. Nutrs. Health Sci. 3:401-409.

Gondokesumo, M.E., H.S.W. Kusuma, \& W. Widowati. 2017. $\alpha-/ \beta$-Glucosidase and $\alpha$-amylase inhibitory activities of roselle (Hibiscus sabdariffa L.) ethanol extract. Mol. Cell Biomed. Sci. 1:34-40. https://doi.org/10.21705/mcbs.v1i1.3

Guetouache, M., G. Bettache, \& M. Samir. 2014. Composition and nutritional value of raw milk. Issues Biol. Sci. Pharm. Res. 2: 115-122.

Hanifah, R., I.I. Arief, C. Budiman. 2016. Antimicrobial activity of goat milk yoghurt with addition of a probiotic Lactobacillus acidophillus IIA-2B4 and roselle (Hibiscus sabdariffa $L$ ) extract. Int. Food Res. J. 23: 2638-2645.

Hariyadi, P. 2013. Freeze Drying: for Better Quality \& Flavor of Dried Products. Foodreview Indonesia. 3:52-57.

Jaafar, S.H.S., R. Hashim, Z. Hassan, \& N. Arifin. 2018. Comparative study on physicochemical characteristics of raw goat milk collected from different farms in Malaysia. Trop. Life Sci. Res. 29:195-212. https://doi.org/10.21315/ tlsr2018.29.1.13

Jitendra, K. \& P. Amit. 2015. An overview of prospective study on functional food. Int. J. Recent Sci. Res. 6:5497-5500.

Kilima, M., S.F. Remberg, B.E. Chove, \& T. Wicklund. 2014. Physio-chemical, mineral composition and antioxidant 
properties of roselle (Hibiscus sabdariffa L.) extract blended with tropical fruit juices. Afr. J. Food Agric. Nutr. Dev. 14:8963-8978

Lacroix, I.M. \& E.C.Y. Li-Chan. 2013. Inhibition of dipeptidyl peptidase (DPP)-IV and $\alpha$-glucosidase activities by pepsintreated whey proteins. J. Agric. Food Chem. 61:75007506. https://doi.org/10.1021/jf401000s

Lawin, P. \& T. Kongbangkerd. 2010. Development of probiotic yoghurt mixed with roselle syrup. KKU Res. J. 15:803-808.

Malelak, G. E. M., H. J. D. Lalel, P. R. Kale, \& I. G. N. Jelantik. 2017. The sensory properties, color, microbial, lipid oxidation, and residual nitrite of se'i marinated with lime and roselle calyces extracts. Med. Pet. 40:194-201. https://doi. org/10.5398/medpet.2017.40.3.194

Marwati, T., N. Cahyaningrum, S. Widodo, T. Januarsyah, \& Purwoko. 2018. Inhibitory activity of bacteriocin produced from Lactobacillus SGC 1223 toward L.monocytogenes, S. thypimurium and E. coli. IOP Conf Ser: Earth Environ Sci.102.

Ministry of Agriculture and Cooperatives. 2008. Thai Agricultural Standard (TAS) 606-2008 Raw Goat Milk. The Royal Thai Government Gazette, 139(139D). Thailand.

Nakhaee, A. \& M. Sanjari. 2013. Evaluation of effect of acarbose consumption on weight losing in non-diabetic overweight or obese patients in kerman. J Res. Med. Sci. 18: 391-394.

Nudyanto, A. \& E. Zubaidah. 2014. Isolasi bakteri asam laktat penghasil eksopolisakarida dari kimchi. Jurnal Pangan dan Agroindustri. 3:743-748.

Papadimitriou, K., A. Alegria, P.A. Bron, M. de Angelis, M. Gobbetti, M. Kleerebezem, J.A. Lemos, D.M. Linares, P. Ross, C. Stanton, F. Turroni, D.V. Sinderen, P. Varmanen, M. Ventura, M. Zuniga, E. Tsakalidou, \& J. Kok. 2016. Stress physiology of lactic acid bacteria. Microbiol. Mol. Biol. Rev. 80:837-890. https://doi.org/10.1128/ MMBR.00076-15

Patil, P., S. Mandal, S.K. Tomar, \& S. Anand. 2015. Food protein-derived bioactive peptides in management of type 2 diabetes. Eur. J. Nutr. 54:863-881. https://doi.org/10.1007/ s00394-015-0974-2

Purbowati, I.S.M., K. Syamsu, E. Warsiki, \& H.S. Rukmini. 2015. Evaluation on toxicity, antibacterial and antioxidant capacity of roselle bioactive compounds with varying solvents. Jurnal Teknologi Industri Pertanian. 25:182-189.

Rosak, C. \& G. Mertes. 2012. Critical evaluation of the role of acarbose in the treatment of diabetes: patient considerations. Diabetes, Metabolic Syndrome and Obesity: Targets and Therapy. 5:357-367. https://doi.org/10.2147/ DMSO.S28340

Sancheti, S., S. Sandesh, \& S. Sung-Yum. 2009. Chaenomeles Sinensis: a potent and $\alpha$ - and $\beta$-Glucosidase inhibitor.
Am. J. Pharmacol. Toxicol. 4: 8-11. https://doi.org/10.3844/ ajptsp.2009.8.11

Shori, A.B. \& A.S. Baba. 2014. Comparative antioxidant activity, proteolysis and in vitro $\alpha$-amylase and $\alpha$-glucosidase inhibition of Allium sativum-yogurts made from cow and camel milk. J. Saudi Chem. Soc. 18: 456-463. https://doi. org/10.1016/j.jscs.2011.09.014

Steel, R.G.D. \& J.H. Torrie. 1980. Principles and Procedures of Statistics. McGraw-Hill Book Co. Inc. New York.

Suharto, E.L.S., I.I. Arief, \& E. Taufik. 2016. Quality and antioxidant activity of yogurt supplemented with roselle during cold storage. Med. Pet. 39: 82-89. https://doi.org/10.5398/ medpet.2016.39.2.82

Sulaiman, N. B., I. I. Arief, \& C. Budiman. 2016. Characteristics of lamb sausages fermented by Indonesian meat-derived probiotic, Lactobacillus plantarum IIA-2C12 and Lactobacillus acidophilus IIA-2B4. Med. Pet. 39:104-111. https://doi. org/10.5398/medpet.2016.39.2.104

Sulistijowati, S. 2012. Potensi Lactobacillus acidophilus ATCC 4796 sebagai biopreservatif pada rebusan daging ikan tongkol. Indonesian Journal of Applied Sciences. 2:604-613.

Sulistiyani, M. Safithri, \& Y.P. Sari. 2016. Inhibition of $\alpha$-glucosidase activity by ethanolic extract of Melia azedarach L. leaves. IOP Conf Ser: Earth Environ Sci. 31.

Tidona, F., A. Criscione, A.M. Guastella, A. Zuccaro, S. Bordonaro, \& D. Marletta. 2009. Milk-derived bioactive peptides in dairy products. Ital. J. Anim. Sci. 8:315-340. https://doi.org/10.4081/ijas.2009.315

Tomovska, J., N. Gjorgievski, \& B. Makarijoski. 2016. Examination of $\mathrm{pH}$, titrable acidity and antioxidant activity in fermented milk. J. Mat. Sci. Eng. 6:326-333.

Tsai, P.J., J. Melntosh, P. Pearce, B. Camden, \& B.R. Jordan. 2002. Anthocyanin and antioxidant capacity in roselle (Hibiscus sabdariffa L) extract. Food Res. Int. 35:351- 356. https://doi.org/10.1016/S0963-9969(01)00129-6

[WHO] World Health Organization. 2016. Global Report on Diabetes. WHO Library Cataloguing-in-Publication Data.

Yu, Z., Y. Yin, W. Zhao, Y. Yu, B. Liu, J. Liu, \& F. Chen. 2011. Novel peptides derived from egg white protein inhibiting alpha-glucosidase. Food Chem. 129: 1376-1382. https:// doi.org/10.1016/j.foodchem.2011.05.067

Zagorska, J. \& I. Ciprovica. 2013. Evaluation of factors affecting freezing point of milk. International Scholarly and Scientific Research \& Innovation. 7:106-111.

Zeng, Z., J. Luo, F. Zuo, Y. Zhang, H. Ma, \& S. Chen. 2016. Screening for potential novel probiotic Lactobacillus strains based on high dipeptidyl peptidase iv and $\alpha$-glucosidase inhibitory activity. J. Funct. Food. 20: 486-495. https://doi. org/10.1016/j.jff.2015.11.030 